\title{
Deoxyribonucleic Acid Base Composition of Flexibacteria
}

\author{
By M. MANDEL \\ Department of Biology, The University of Texas, M. D. Anderson Hospital \\ and Tumor Institute at Houston, Houston, Texas 77025, U.S.A. \\ AND R. A. LEWIN \\ Scripps Institution of Oceanography, University of California, \\ San Diego, La Jolla, California 92038, U.S.A. \\ (Accepted for publication 4 June 1969) \\ SUMMARY \\ The base compositions of the deoxyribonucleic acids extracted from 93 \\ cultures of flexibacteria classified in the genera Cytophaga, Flexibacter, \\ Microscilla, Saprospira, Herpetosiphon, Vitreoscilla and Beggiatoa have been \\ determined. The data demonstrate that the guanine plus cytosine contents \\ (GC values) of the representative cultures ranged from 30 to $53 \%$. A number \\ of the recently proposed nomen species are shown to contain representatives \\ with different GC values.
}

\section{INTRODUCTION}

Marmur, Falkow \& Mandel (1963) reviewed the arguments for considering comparative analyses of DNA base compositions as a cardinal criterion in microbial taxonomy. In brief, they concluded that a necessary, but not sufficient, condition for substantial genetic homology between pairs of organisms is an overall similarity in DNA base composition. As the difference in composition increases, so does the likelihood of less homology, and hence greater evolutionary divergence. A critical parameter in this regard is the ' $\mathrm{GC}$ value', the proportion of guanine + cytosine in the deoxyribonucleic acid, expressed as a molar percentage of total bases.

In this paper we present GC values obtained by density-gradient determinations for DNA of 90 of the strains of flexibacteria isolated and characterized by Lewin \& Lounsbery (I969), and for three other organisms. These data were used, together with other biochemical and physiological information, in a computer analysis designed to associate these microbes in groups which could serve as a basis for their classification (Fager, 1969). Largely on the basis of Fager's analysis Lewin (1969) assigned these strains to a number of named genera and species. In the present paper, we also discuss the status of Lewin's proposed taxa as viewed solely from the standpoint of their GC values.

\section{METHODS}

Organisms were harvested by centrifugation of cultures in liquid media when they had attained maximum growth as described by Lewin \& Lounsbery (1969). The organisms were suspended in a small volume of $0 \cdot I_{5} \mathrm{M}-\mathrm{NaCl}$ containing $\mathrm{O} \cdot \mathrm{I} \mathrm{M}-\mathrm{Na}_{2}$ ethylenediamine tetra-acetate(EDTA) at $\mathrm{pH} 8 \cdot 0$ (saline EDTA) and were lysed by the addition of sodium dodecyl (lauryl) sulphate to a final concentration of $2 \%(\mathrm{w} / \mathrm{v})$. The lysate was immediately deproteinized with fresh phenol saturated with saline-EDTA at neutral $\mathrm{pH}$, the aqueous phase separated by centrifugation, and the DNA precipitated from it by the 
addition of two volumes of $99 \%(\mathrm{v} / \mathrm{v})$ ethanol was 'spooled' on a clean glass rod. Spools prepared in California were shipped in ethanol to Texas for analysis. The spool was freed of phenol by successive immersions in two changes of $70 \%(\mathrm{v} / \mathrm{v})$ ethanol in water, drained, and then dissolved in $0.15 \mathrm{M}-\mathrm{NaCl}+0.015 \mathrm{M}-\mathrm{Na}_{3}$ citrate at $\mathrm{pH} 7.0$ (solution SSC). When samples were to be analysed by thermal denaturation, highly purified DNA was prepared from the lysates by the procedure of Marmur (I96I). All samples were stored over $\mathrm{CHCl}_{3}$ at $5^{\circ}$ until they were analysed.

\section{Table I. Buoyant density and GC content of DNA of flexibacteria}

Values given for mean density are averages of at least two determinations of the buoyant density in $\mathrm{CsCl}$ at 44,770 and $42,040 \mathrm{rev}$. $/ \mathrm{min}$. Specific epithets and strain numbers correspond to the designations of Lewin (1969).

\begin{tabular}{|c|c|c|c|}
\hline Name & Strain & $\begin{array}{l}\text { Mean density } \\
\left(\mathrm{g} \cdot / \mathrm{cm} .^{3}\right)\end{array}$ & $\begin{array}{c}\text { GC } \\
(\text { mole } \%)\end{array}$ \\
\hline Cytophaga latercula & SIO-I & I 6935 & $34 \cdot 2$ \\
\hline C. lytica & $\begin{array}{l}\text { B-9 } \\
\text { WFB-2 I } \\
\text { BON } \\
\text { ENS } \\
\text { LIM-2 I }\end{array}$ & $\begin{array}{l}I \cdot 6925 \\
I \cdot 6935 \\
I \cdot 693\left(I \cdot 7 I 65^{*}\right) \\
I \cdot 6925 \\
I \cdot 693\end{array}$ & $\begin{array}{l}33 \cdot 2 \\
34 \cdot 2 \\
33 \cdot 7\left(57 \cdot 7^{*}\right) \\
33 \cdot 2 \\
33 \cdot 2\end{array}$ \\
\hline $\begin{array}{l}\text { C. diffluens (?) } \\
\text { C. diffluens var. aprica }\end{array}$ & $\begin{array}{l}\text { DD-I } \\
\text { DUB-4 } \\
\text { ST-I } \\
\text { JL-4 }\end{array}$ & $\begin{array}{l}I .694 \\
I .696 \\
I .6965 \\
I .6945\end{array}$ & $\begin{array}{l}34 \cdot 7 \\
36 \cdot 7 \\
37 \cdot 2 \\
35 \cdot 2\end{array}$ \\
\hline C. diffluens var. carnea & Q-I & I.6965 & $37 \cdot 2$ \\
\hline C. diffluens & $\begin{array}{l}\text { Y-I } \\
\text { GOL-I2 } \\
\text { N-3 } \\
\text { NN-3 } \\
\text { B-I } \\
\text { LIM-I } \\
\text { O-2 }\end{array}$ & $\begin{array}{l}I \cdot 700 \\
I \cdot 700 \\
I \cdot 6995 \\
I \cdot 6995 \\
I \cdot 7015 \\
I \cdot 7015 \\
I \cdot 7007\end{array}$ & $\begin{array}{l}40 \cdot 8 \\
40 \cdot 8 \\
40 \cdot 3 \\
40 \cdot 3 \\
42 \cdot 3 \\
42 \cdot 3 \\
41 \cdot 5\end{array}$ \\
\hline Flexibacter litoralis & SIO-4 & I 6897 & $30 \cdot 3$ \\
\hline F. aurantiacus & $\begin{array}{l}\text { DWO } \\
\text { PSY }\end{array}$ & $\begin{array}{l}\text { I.6905 } \\
\text { I. } 6910\end{array}$ & $\begin{array}{l}3 I \cdot I \\
3 I \cdot 6\end{array}$ \\
\hline F. aurantiacus var. copepodarus & COP & $I \cdot 691$ & $3 I \cdot 6$ \\
\hline F. aurantiacus var. excathedrus & CR-I34 & $1 \cdot 6935$ & $34 \cdot 2$ \\
\hline F.giganteus & $\begin{array}{l}\text { CR-IO3 } \\
\text { CR-IO4 } \\
\text { CR-I } 24\end{array}$ & $\begin{array}{l}I \cdot 6925 \\
I \cdot 69 I \\
I \cdot 6906\end{array}$ & $\begin{array}{l}33 \cdot 2 \\
3 I \cdot 6 \\
3 I \cdot 2\end{array}$ \\
\hline F. roseolus & $\begin{array}{l}\text { CR-I } 41 \\
\text { CR-I } 55\end{array}$ & $\begin{array}{l}I .6935 \\
I \cdot 698\end{array}$ & $\begin{array}{l}34 \cdot 2 \\
38 \cdot 8\end{array}$ \\
\hline F. ruber & GEY & $1 \cdot 696$ & $36 \cdot 7$ \\
\hline F. flexilis & $\begin{array}{l}\text { CR-63 } \\
\text { CR-8I } \\
\text { A-52 } \\
\text { WAR-5 }\end{array}$ & $\begin{array}{l}I \cdot 700 \\
I \cdot 702 \\
I \cdot 7015 \\
I \cdot 6995\end{array}$ & $\begin{array}{l}40 \cdot 8 \\
42 \cdot 9 \\
42 \cdot 3 \\
40 \cdot 3\end{array}$ \\
\hline F. flexilis var. pelliculosus & FLE & $1 \cdot 6985$ & $39 \cdot 3$ \\
\hline F. flexilis var. iolanthae & BA-24 & $I \cdot 7005$ & $4 I \cdot 3$ \\
\hline$F$. sancti & $\begin{array}{l}\text { BA-3 } \\
\text { BA-23 } \\
\text { MIC }\end{array}$ & $\begin{array}{l}I \cdot 705 \\
I \cdot 706 \\
I \cdot 705\end{array}$ & $\begin{array}{l}45 \cdot 9 \\
46 \cdot 9 \\
45 \cdot 9\end{array}$ \\
\hline F. elegans & NZ-I & $I \cdot 7065$ & $47 \cdot 4$ \\
\hline
\end{tabular}


(Table I cont.)

\begin{tabular}{|c|c|c|c|}
\hline Name & Strain & $\begin{array}{l}\text { Mean density } \\
\left(\mathrm{g} . / \mathrm{cm}^{3}\right)^{3}\end{array}$ & $\begin{array}{c}\text { GC } \\
(\text { mole \%) }\end{array}$ \\
\hline Microscilla arenaria & HJ-I & $I \cdot 69 I 5$ & $32 \cdot I$ \\
\hline \multirow[t]{5}{*}{ M. aggregans } & Q-3 & $I \cdot 70 I 5$ & $42 \cdot 3$ \\
\hline & QQ-I & $I \cdot 6985$ & $39 \cdot 3$ \\
\hline & QQ-I I & $I \cdot 6993$ & $40 \cdot I$ \\
\hline & JL-I 3 & $\mathrm{I} \cdot 695$ & $35 \cdot 7$ \\
\hline & NN-13 & $I \cdot 696$ & $36 \cdot 7$ \\
\hline \multirow{2}{*}{$\begin{array}{l}\text { M. aggregans var. catalatica } \\
\text { (Flexithrix dorotheae })\end{array}$} & HI-3 & $I \cdot 694$ & $34 \cdot 7$ \\
\hline & QQ-3 & $I \cdot 6965$ & \\
\hline \multirow[t]{8}{*}{ Microscilla tractuosa } & EE-13 & $\mathrm{I} \cdot 697$ & $37 \cdot 8$ \\
\hline & EG-13 & $1 \cdot 6965$ & $37 \cdot 2$ \\
\hline & GH-I & $x \cdot 6935$ & 34.2 \\
\hline & GH-2 & $1 \cdot 6945$ & $35 \cdot 2$ \\
\hline & HI-I 5 & $I \cdot 695$ & $35 \cdot 7$ \\
\hline & H-43 & $1 \cdot 6955$ & $36 \cdot 2$ \\
\hline & JK-I I & $1 \cdot 696$ & $36 \cdot 7$ \\
\hline & $T-13$ & $1 \cdot 6965$ & $37 \cdot 2$ \\
\hline \multirow[t]{2}{*}{ M. sericea } & SIO-7 & I 698 & $38 \cdot 8$ \\
\hline & sio-9 & $1 \cdot 698$ & $38 \cdot 8$ \\
\hline M. marina & sio-8 & $I \cdot 7015$ & $42 \cdot 3$ \\
\hline M. furvescens & TV-2 & I·704 & $44 \cdot 9$ \\
\hline \multirow[t]{3}{*}{ Saprospira thermalis } & BEG & $I \cdot 696$ & $36 \cdot 7$ \\
\hline & CR-I 23 & I 6947 & 35.4 \\
\hline & CR-1 25 & $1 \cdot 692$ & $32 \cdot 7$ \\
\hline S. toviformis & A-I & $I \cdot 6976$ & $38 \cdot 4$ \\
\hline \multirow[t]{3}{*}{ S. albida } & CAR & I.699 & $39 \cdot 8$ \\
\hline & HH & $1 \cdot 7015$ & $42 \cdot 3$ \\
\hline & MUR & $I \cdot 702$ & $42 \cdot 9$ \\
\hline \multirow[t]{7}{*}{ S. grandis } & WH & I· 7068 & $47 \cdot 8$ \\
\hline & PA-I & $I \cdot 7064$ & $47 \cdot 3$ \\
\hline & PA-2 & $\mathrm{I} \cdot 7055$ & $46 \cdot 4$ \\
\hline & PA-3 & I $\cdot 7055$ & $46 \cdot 4$ \\
\hline & LJA & I 7058 & $46 \cdot 7$ \\
\hline & E-I & $I \cdot 7055$ & $46 \cdot 4$ \\
\hline & $E-2$ & $I \cdot 707$ & $48 \cdot 0$ \\
\hline \multirow[t]{12}{*}{ S. grandis } & $M-1$ & $I \cdot 7065$ & $47 \cdot 4$ \\
\hline & $M-2$ & $I \cdot 7065$ & $47 \cdot 4$ \\
\hline & ROB & $I \cdot 7065$ & $47 \cdot 4$ \\
\hline & SG-I & $1 \cdot 706$ & $46 \cdot 9$ \\
\hline & SG-2 & $\mathbf{I} \cdot 707$ & $48 \cdot 0$ \\
\hline & DAW-I & $I \cdot 707$ & $48 \cdot 0$ \\
\hline & DAW-2 & $I \cdot 706$ & $46 \cdot 9$ \\
\hline & DUB-2 & $I \cdot 706$ & $46 \cdot 9$ \\
\hline & DUB-3 & $1 \cdot 705$ & $45 \cdot 9$ \\
\hline & $A-2$ & $I \cdot 705$ & $45 \cdot 9$ \\
\hline & $A-3$ & $I \cdot 705$ & $45 \cdot 9$ \\
\hline & JL-I & $I \cdot 7065$ & $47 \cdot 4$ \\
\hline S. flammula & SNZ & $I \cdot 7073$ & $48 \cdot 3$ \\
\hline Herpetosiphon cohaerens & II-2 & $\mathbf{I} \cdot 704$ & $44 \cdot 9$ \\
\hline H. persicus & $T-3$ & $1 \cdot 7$ I I 5 & $52 \cdot 6$ \\
\hline$H$. nigricans & SS-2 & $\mathbf{I} \cdot 7 \mathbf{I} 2$ & $53 \cdot I$ \\
\hline H.geysericolus & GC-42 & $I \cdot 7075$ & $48 \cdot 5$ \\
\hline
\end{tabular}

* Second component present in trace amount. 
The buoyant density in $\mathrm{CsCl}$ was determined as described by Schildkraut, Marmur $\&$ Doty (1962). All samples were analysed at least once in each of two different analytical ultracentrifuges, one operating at $44,770 \mathrm{rev} . / \mathrm{min}$. and recording photographically, the other operating at $42,040 \mathrm{rev} . / \mathrm{min}$. and using a photoelectric multiplier scanning system. (For details of operation, see Mandel, Schildkraut \& Marmur, 1968.) Samples of I to $2 \mu \mathrm{g}$. of the DNA of unknown density were brought to isopycnic equilibrium in $\mathrm{CsCl}$ gradients containing as a reference sample $0.5 \mu \mathrm{g}$. DNA of bacteriophage SP 8 of a density of $1.742 \mathrm{~g} . / \mathrm{cm} .^{3}$ (calibrated against DNA of Escherichia coli, assumed to be of a density of $\left.1 \cdot 710 \mathrm{~g} . / \mathrm{cm}^{3}{ }^{3}\right)$. The guanine + cytosine (GC) content of the extracted DNA was estimated from the mean buoyant density as described in the above references. This is the GC value as discussed throughout this paper.

Thermal denaturation was done in solution SSC at a DNA concentration of $20 \mu \mathrm{g}$./ ml. using a Beckman DU spectrophotometer, as described by Marmur \& Doty (1962).

\section{RESULTS}

The results are summarized in Tables I (all strains examined) and Table 2 (combined data for species).

\section{Cytophaga}

The 18 strains assigned to the genus Cytophaga had GC values of 33 to $42 \%$. The strain BON, assigned to Cytophaga lytica, yielded DNA which displayed also a second minor component at equilibrium in the $\mathrm{CsCl}$ gradient. Upon heat denaturation both major and minor bands increased in density by about $\mathrm{I} 5$ and $\mathrm{I} 2 \mathrm{mg} . / \mathrm{cm} .{ }^{3}$ respectively; hence we concluded that each was a double stranded DNA molecule. No obvious contaminating organism has been isolated from this culture, but the possibility of contamination has not been excluded beyond question.

The strains assigned to $C$. lytica were homogeneous with respect to $\mathrm{GC}$ values. The standard deviation of the twelve analyses $\left(0.0008 \mathrm{~g} . / \mathrm{cm} . .^{3}\right)$ was not appreciably different from the standard deviation usually encountered when a like number of analyses is performed on a single DNA sample. The single strain assigned to C. latercula had a $\mathrm{GC}$ value similar to that of C. lytica.

The remaining strains assigned to the genus Cytophaga can be conveniently divided into two groups (Table 2). The first group, with a mean GC value of about $36 \%$, included the strain DD-I, tentatively assigned to C.diffluens, and the varieties C.diffluens var. aprica and $C$. diffluens var. carnea. The standard deviation of the analyses is somewhat large and may indicate a lack of homogeneity in this group. The second group, also assigned to the species $C$. diffluens, had a $\mathrm{GC}$ value of about $4 \mathrm{I} \%$ and appears homogeneous.

\section{Flexibacter}

Lewin (1969) assigned to the genus Flexibacter 2 I strains ranging in GC value from 30 to $47 \%$ (Table I). The monotypic $F$. litoralis represented the low extreme, with not very different values observed for the groups designated as $F$. aurantiacus and $F$. giganteus. The combination of $F$. aurantiacus with its varities copepodarus and excathedrus yielded a standard deviation that appeared uncomfortably large (see Table 2). If strain GR-I 34 were to be excluded from this group, the S.D. would be appreciably decreased A similar reservation has to be made for the association of the three strains 
included under $F$. giganteus. $F$. roseolus is represented by two isolates with significantly different GC values, of the order of 4 to $5 \%$ apart, indicating that the organisms may be related but are not likely to be members of the same genospecies in the sense of Ravin (1963). The strain designated as $F$. ruber had a GC value intermediate between the two values for the strains of $F$. roseolus. Six isolates assigned to $F$. flexilis and its varieties pelliculosus and iolanthae have GC values ranging from 39 to $43 \%$, with a mean of $4 \mathrm{I} \cdot 6 \%$ and a standard deviation of $\mathrm{I} \cdot 6 \%$. We conclude that these groups, too, display inhomogeneity in this regard, although there is no obvious way by which an effective division may be made with the data at hand. The three strains assigned to $F$. sancti comprised a uniform assemblage with GC values of $46 \cdot 2 \pm 0 \cdot 9 \%$. The single strain of $F$. elegans was only slightly but not significantly richer in GC content, its value being $47 \cdot 4 \%$.

\section{Table 2. Buoyant density and GC content of DNA calculated for groups of strains of flexibacteria}

\begin{tabular}{|c|c|c|c|}
\hline \multirow[b]{2}{*}{ Species or group } & \multirow[b]{2}{*}{ No. of analyses } & \multicolumn{2}{|c|}{$\begin{array}{c}\text { Mean value and standard } \\
\text { deviation }\end{array}$} \\
\hline & & Density $\left(\mathrm{g} . / \mathrm{cm} .{ }^{3}\right)$ & GC (moles \%) \\
\hline $\begin{array}{l}\text { Cytophaga latercula } \\
\text { C. lytica } \\
\text { C. diffluens group I } \\
\text { C. diffluens group II }\end{array}$ & $\begin{array}{l}(2) \\
(12) \\
(10) \\
(16)\end{array}$ & $\begin{array}{l}I \cdot 6935 \\
I \cdot 6929 \pm 0.0008 \\
I \cdot 6955 \pm 0.0014 \\
I \cdot 7000 \pm 0.0010\end{array}$ & $\begin{array}{l}34 \cdot 2 \\
33 \cdot 6 \pm 0 \cdot 8 \\
36 \cdot 2 \pm I \cdot 4 \\
40 \cdot 8 \pm I \cdot 0\end{array}$ \\
\hline $\begin{array}{l}\text { Flexibacter litoralis } \\
\text { F. aurantiacus group } \\
\text { F. giganteus } \\
\text { F. roseolus } \\
\text { F. ruber } \\
\text { F. flexilis group } \\
\text { F. sancti } \\
\text { F. elegans }\end{array}$ & $\begin{array}{r}(4) \\
(8) \\
(9) \\
(4) \\
(2) \\
(14) \\
(6) \\
(2)\end{array}$ & $\begin{array}{l}I \cdot 6897 \pm 0.0005 \\
I \cdot 6915 \pm 0.0014 \\
I \cdot 6911 \pm 0.0013 \\
I \cdot 6958 \pm 0.0026 \\
I \cdot 696 \\
I \cdot 7004 \pm 0.0016 \\
I \cdot 7053 \pm 0.0009 \\
I \cdot 7065\end{array}$ & $\begin{array}{l}30 \cdot 3 \pm 0 \cdot 5 \\
32 \cdot I \pm I \cdot 4 \\
3 I \cdot 7 \pm I \cdot 3 \\
36 \cdot 5 \pm 2 \cdot 6 \\
36 \cdot 7 \\
4 I \cdot 6 \pm 1 \cdot 6 \\
46 \cdot 2 \pm 0 \cdot 9 \\
47 \cdot 4\end{array}$ \\
\hline $\begin{array}{l}\text { Microscilla arenaria } \\
\text { M. aggregans group } \\
\quad \text { (Flexithrix dorotheae) } \\
\text { M. tractuosa } \\
\text { M. sericea } \\
\text { M. marina } \\
\text { M. furvescens }\end{array}$ & $\begin{array}{r}(2) \\
(15) \\
(2) \\
(16) \\
(4) \\
(2) \\
(2)\end{array}$ & $\begin{array}{l}I \cdot 6915 \\
I \cdot 6974 \pm 0.0025 \\
I \cdot 6965 \\
I \cdot 6956 \pm 0.0013 \\
I \cdot 698 \pm 0.0008 \\
I \cdot 7015 \\
I \cdot 704\end{array}$ & $\begin{array}{l}32 \cdot I \\
38 \cdot 2 \pm 2 \cdot 5 \\
37 \cdot 2 \\
36 \cdot 3 \pm I \cdot 3 \\
38 \cdot 8 \pm 0 \cdot 8 \\
42 \cdot 3 \\
44 \cdot 9\end{array}$ \\
\hline $\begin{array}{l}\text { Saprospira thermalis } \\
\text { S. toviformis } \\
\text { S. albida } \\
\text { S. grandis } \\
\text { S. flammula }\end{array}$ & $\begin{array}{r}(10) \\
(5) \\
(6) \\
(49) \\
(4)\end{array}$ & $\begin{array}{l}I \cdot 6947 \pm 0.0022 \\
I \cdot 6976 \pm 0.0009 \\
I \cdot 7005 \pm 0.0015 \\
I \cdot 706 I \pm 0.0009 \\
I \cdot 7073 \pm 0.0010\end{array}$ & $\begin{array}{l}35 \cdot 4 \pm 2 \cdot 2 \\
38 \cdot 4 \pm 0 \cdot 9 \\
4 I \cdot 3 \pm I \cdot 5 \\
47 \cdot 0 \pm 0 \cdot 9 \\
48 \cdot 3 \pm I \cdot 0\end{array}$ \\
\hline $\begin{array}{l}\text { Herpetosiphon cohaerens } \\
\text { H. persicus } \\
\text { H. nigricans } \\
\text { H. gevsericolus }\end{array}$ & $\begin{array}{l}(2) \\
(2) \\
(2) \\
(2)\end{array}$ & $\begin{array}{l}I \cdot 704 \\
I \cdot 7 \text { I } 15 \\
I \cdot 712 \\
I \cdot 7075\end{array}$ & $\begin{array}{l}44 \cdot 9 \\
52 \cdot 6 \\
53 \cdot 1 \\
48 \cdot 5\end{array}$ \\
\hline
\end{tabular}

Microscilla and Flexithrix

In this group of 20 strains, Microscilla arenaria was at the lower limit with a GCvalue of $32 \%$, and $M$. furvescens was at the other extreme with a value of $45 \%$. The $M$. aggregans group appeared to be heterogeneous in this respect, and might be better subdivided into a group of 3 strains, Q-3, QQ-I and QQ-I I, with a mean GC value of $4 \mathrm{I} \%$ and a second group, JL-I3, and NN-I3, which, together with the variety catalatica (HI-3), would have 
a mean value of $36 \%$. The strain QQ-3, bearing the provisional epithet Flexithrix dorotheae, might have an affinity with this latter group or with members of the $M$. tractuosa group. Members of this group, with an average GC value of $36 \cdot 3 \pm 1 \cdot 3 \%$, may eventually prove to be divisible into at least two species. The two strains assigned to $M$. sericea had indistinguishable GC values. The remaining strain, designated as $M$. marina, had a GC value of $42 \%$, it was thereby readily distinguished from all other strains of the Microscilla group except the higher GC subgroup of $M$. aggregans.

\section{Saprospira}

Of the 27 strains assigned to this genus, I9 are considered to be representative of Saprospira grandis; the similarity of their GC values (Table I) is in agreement with this conclusion. The mean value for this species was $47 \cdot 0 \pm 0.9 \%$. Strain A-I was originally considered to be a member of this species, but the lower density of its DNA indicated a GC value of about $38 \%$. (Melting curves confirmed this difference: the DNA of A-I melted at a temperature 4 to $5^{\circ}$ below that of the DNA from DAW-3). Further phenotypic characterization led to our decision to distinguish this strain as a separate monotypic species, Saprospira toviformis (Lewin \& Mandel, 1969).

The representatives of $S$. thermalis had DNA base compositions quite distinct from those of $S$. grandis. The GC value for strain CR-I $25(33 \%)$ was lower than that obtained for BEG and CR-I 23 ( 35 to $37 \%$ ), which it otherwise closely resembled. (In fact, CR-I 23 and CR-I 25 were isolated from the same mud sample).

The strain SNZ, designated as S. flammula (Lewin, 1965), did not differ significantly in base composition from $S$. grandis, which it closely resembled also in phenotypic appearance, pigmentation and nutrition. Although originally isolated from a nonsaline hot spring, it grew well in marine media, so we cannot regard it as specifically distinct from Saprospira grandis.

The three strains designated as $S$. albida had GC values very close to $4 \mathrm{I} \%$.

\section{Herpetosiphon}

Holt \& Lewin (1968) described a new genus of sheathed gliding bacteria with the type species Herpetosiphon aurantiacus. Three strains of this species were examined and found to have GC values of $48 \cdot \mathrm{I} \pm \mathrm{I} \cdot 2 \%$. Four other isolates of morphologically similar filamentous organisms have been assigned to this genus (Lewin 1969). The strain designated as $H$. geysericolus had a GC value indistinguishable from that of the type species $H$. aurantiacus. The representative of $H$. cohaerans was significantly lower in GC content ( $45 \%$ ), while $H$. persicus and $H$. nigricans each had GC values about $53 \%$. The genus is therefore clearly divisible into at least three species on the basis of GC values.

\section{Other apochlorotic gliding microbes}

We have determined the DNA base compositions of a few similar organisms other than those included in the study of Lewin \& Lounsbery (1969). A Vitreoscilla strain provided by Dr B. J. Bachmann (originally isolated by Professor E. G. Pringsheim) had a DNA of a buoyant density indicating a GC value of $43.6 \%$ : it was thus indistinguishable from strain V-I obtained from Dr C. Hageage. Professor R. Y. Morita provided a cell harvest of Beggiatoa leptomitiformis, grown as described by Burton \& Morita (1964); we obtained for this sample a GC value of $37 \%$. 


\section{DISCUSSION}

The GC values obtained for 90 of the cultures of flexibacteria studied by Lewin \& Lounsbery (1969) ranged from $3 \mathrm{I}$ to $53 \%$.

The I 8 cultures assigned to the genus Cytophaga all had GC values between 33 and $42 \%$, within the range previously reported for that genus by Mandel \& Leadbetter (1965). Among the strains assigned by Lewin (1969) to C. diffluens, the range of GC values may be too wide for a single species, and it is to be expected that further studies of this group will lead to its division into at least two, possibly three, species.

The 21 cultures assigned to the genus Flexibacter ranged in GC values from 30 to $48 \%$. Since most of the species were represented by no more than a few strains, judgements as to homogeneity of $\mathrm{GC}$ values can be only tentative. The $\mathrm{GC}$ values obtained for two strains assigned to $F$. roseolus differed by at least $4 \%$, and perhaps strain CR-I $4 \mathrm{I}$ should be set apart as a separate species.

The 20 cultures of the genus Microscilla had GC values ranging from 32 to $45 \%$ GC. Microscilla aggregans and $M$. tractuosa may eventually prove to embrace more than one species.

The genus Saprospira, represented by 27 isolates, had members with GC values of 53 to $48 \%$. We have reservations as to the uniformity of the members of $S$. thermalis and S. albida. S. toviformis and S. flammula are monotypic; the latter cannot be separated from $S$. grandis on the basis of base composition.

The genus Herpetosiphon had representatives whose GC values ranged from 45 to $53 \%$. Three species are monotypic at present, while in the type species, H. auranticiacus, the three strains are nearly identical in DNA base composition, with GC values averaging $48 \%$.

The GC values of the Vitreoscilla cultures and of Beggiatoa leptomitiformis, as reported in this paper, were within the range found for the filamentous flexibacteria. Leucothrix strains have been reported with GC values, 47 to $49 \%$ in the same range (Brock \& Mandel, I966).

The gliding bacteria may be regarded as apochlorotic relatives of the filamentous Cyanophyta, notably the Oscillatoriales (Pringsheim, I949; Harold \& Stanier, I955). Edelman et al. (1967) found GC values for 29 representatives of the blue-green algae to range from 35 to $7 \mathrm{I} \%$, and commented upon the overlap of GC values for the filamentous gliding bacteria and the Oscillatoriales. In their survey, the 22 representatives of the order Oscillatoriales had GC values which ranged from 39 to $5 \mathrm{I} \%$. Zimmerman (1966) reported that a strain of Anacystis nidulans had a GC value of $49 \%$ ( $c f$. the value $56 \%$ reported by Edelman et al. 1967). This strain, when obtained originally from Kratz via Myers, has apparently been incorrectly identified, and should more correctly be called Phormidium mucicola (Silva, 1962). Its GC value falls neatly in the range of the Oscillatoriales. The additional data now available for filamentous flexibacteria extend the range of their GC values below those for bluegreen algae. The argument for relatedness is strengthened by the coincidence of GC values for the sheathed representatives, Lyngbya (47 and $51 \%$ ) and Herpetosiphon (44 to $53 \%$ ).

The invaluable assistance of Janet Bergendahl and the gift of equipment from the $\mathrm{Mr}$ and Mrs T. N. Law Foundation is gratefully acknowledged. 


\section{REFERENCES}

Brock, T. D. \& MANDEL, M. (1966). Deoxyribonucleic acid base composition of geographically diverse strains of Leucothrix mucor. J. Bact. 9r, 1659.

Burton, S. D. \& Morita, R. Y. (I964). Effect of catalase and cultural conditions on growth of Beggiatoa. J. Bact. 88, 1755.

Edelman, M., Swinton, D., Schiff, J. A., Epstein, H. T. \& Zeldin, B. (1967). Deoxyribonucleic acid of the blue-green algae (Cyanophyta). Bact. Rev. 31, 315 .

FAGER, E. W. (1969). Recurrent group analysis in the classification of flexibacteria. J. gen. Microbiol. $58,179$.

Harold, R. \& Stanier, R. Y. (I955). The genera Leucothrix and Thiothrix. Bact. Rev. 19, 49.

HolT, J. G. \& LewIN, R. A. (I968). Herpetosiphon aurantiacus gen. et sp. n., a new filamentous gliding organism. J. Bact. 95, 2407.

LewIN, R. A. (I965). Freshwater species of Saprospira. Can. J. Microbiol. Ir, I35.

LEwIN, R. A. (I969). A classification of flexibacteria. J. gen. Microbiol. 58, 189.

LEWIN, R. A. \& LounsBery, D. M. (1969). Isolation, cultivation and characterization of flexibacteria. J. gen. Microbiol. 58, 145 .

Lewin, R. A. \& MANDEL, M. (1969). Saprospira toviformis nov. spec. (Flexibacterales) from a New Zealand sea-shore. Can. J. Microbiol. (in the Press).

MANDEL, M. \& LeadBetTeR, E. R. (1965). Deoxyribonucleic acid base composition of myxobacteria. J. Bact. 90, I 795 .

Mandel, M., Schildkraut, C. L. \& Marmur, J. (1968). Use of CsCl density gradient analysis for determining the guanine plus cytosine content of DNA. Meth. Enzym. 12, I84.

MARMUR, J. (1961). A procedure for the isolation of deoxyribonucleic acid from micro-organisms. J. molec. Biol. 3, 208.

Marmur, J. \& DoTY, P. (I962). Determination of the base composition of deoxyribonucleic acid from its thermal denaturation temperature. J. molec. Biol. 5, 109.

Marmur, J., Falkow, S. \& Mandel, M. (I963). New approaches to bacterial taxonomy. A. Rev. Microbiol. 17, 329.

Pringsheim, E. G. (1949). The relationship between bacteria and Myxophyceae. Bact. Rev. $13,47$.

Ravin, A. W. (1963). Experimental approaches to the study of bacterial phylogeny. Am. Nat. $97,307$.

Schildkraut, C. L., Marmur, J. \& DotY, P. (1962). Determination of the base composition of deoxyribonucleic acid from its buoyant density in CsCl. J. molec. Biol. 4, 430.

Silva, P. C. (1962). Classification of algae (footnote 2). In Physiology and Biochemistry of Algae. Ed. by R. A. Lewin. London: Academic Press.

Zimmerman, B. K. (1966). Micrococcus lysodeikticus deoxyribonucleic acid polymerase. J. biol. Chem. 241, 2035. 